\title{
Rectal Ointment Dosage Form
}

National Cancer Institute

\section{Source}

National Cancer Institute. Rectal Ointment Dosage Form. NCI Thesaurus. Code C69047.

An ointment intended for administration in or around the rectum. 